\title{
KONSTITUSIONALITAS HAK ANGKET DEWAN PERWAKILAN RAKYAT (DPR) TERHADAP KOMISI PEMBERANTASAN KORUPSI (KPK)
}

\author{
Ismail Aris ${ }^{1}$, Irfan Amir ${ }^{2}$, Septian Amrianto ${ }^{3}$ \\ Konsentrasi Hukum Tata Negara \\ E-mail: ismail.aris239@gmail.com.
}

\begin{abstract}
The development of the state institutional theory requires that it no longer seals every State institution only to depend on 3 (three) branches of power as the teaching of the new separation of power theory. On the other hand, the decision of the Constitutional Court and the Revision of the KPK Law are placed as executive institutions. So it is debated whether the KPK is a subject that can be rounded up, because it is an executive institution or the KPK cannot be made a subject of questionnaire rights because of its position as an independent agency agency? This study aims to determine and analyze the authority of the DPR's questionnaire rights to the KPK and the constitutionality of the DPR's Questionnaire Rights to the KPK Perspectives on the revision of the KPK Law and Comparison in Various Countries. This type of research is the type of normative legal research. The approach used is the legislation approach and comparative law (comparison approach), the philosophical approach to the law (philosophical approach).

The results of the study showed that the constitutionality of the DPR questionnaire rights was based on the original intent of the questionnaire right norm in a comprehensive draft amendment to the Basic Law, the questionnaire right was only aimed at state institutions of the executive family. In addition, Constitutional Court Decision No. 36-40 / PUU-XV / 2017, which categorizes the Corruption Eradication Commission as a group of executive institutions is in conflict with other Constitutional Court decisions, namely Decision of the Constitutional Court Number 012-016-019 / PUU-IV / 2006, 19 / PUU-V / 2007, 37-39 / PUU-VIII / 2010. 5 / PUU-IX / 2011, places the KPK as an independent agency and is categorized as faste jurisprudence (permanent jurisprudence). In addition, theoretically, the teaching of the new theory of separation of power teaches that it is no longer appropriate to place State institutions based only on 3 (three) branches of power. While the constitutionality of the DPR's questionnaire rights to the KPK Perspective of the revision of the KPK Law and Comparison in Various Countries is based on the results of research by researchers that the $K P K^{\prime}$ s position in various countries is independent or dependent. For example, in South Africa, Zimbabwe, Egypt and Thailand. Likewise with the subject of state institutions that can be researched, there are no countries that address the right of
\end{abstract}

\footnotetext{
${ }^{1}$ Dosen Tetap Hukum Tata Negara STAI Al Gazali Bone dan Advokat di Kantor Hukum Ismail Aris and Parnerts.

${ }^{2}$ Prodi Hukum Tata Negara, Institut Agama Islam Negeri (IAIN) Bone

${ }^{3}$ Forum Kajian Konstitusi dan Hak Asasi Manusia (FKK HAM) IAIN Bone
} 
questionnaires to these independent institutions. For example, the United States of America, Philippines, South Africa, all of whom address the questioning right of inquiry only as an executive state institution.

Keywords: Congressional oversight, Corruption Eradication Commission.

\begin{abstract}
Abstrak
Perkembangan teori kelembagaan Negara mengharuskan tidak lagi untuk mendudukkan setiap lembaga Negara hanya bergantung pada 3 (tiga) cabang kekuasaan sebagaimana ajaran teori the new separation of power. Di sisi lainnya, putusan Mahkamah Konstitusi dan Revisi Undang-Undang KPK tempatkan sebagai lembaga eksekutif. Sehingga menjadi perdebatan apakah KPK sebagai subjek yang dapat diangket, karena sebagai lemebaga eksekutif ataukah KPK tidak dapat dijadikan sebagai subjek hak angket karena posisinya sebagai lembaga independent agencies? Penelitian ini bertujuan untuk mengetahui dan menganalisis kewenangan hak angket DPR terhadap KPK dan Konstitusionalitas Hak Angket DPR terhadap KPK Perspektif revisi UU KPK dan Perbandingan di Berbagai Negara. Tipe penelitian ini yakni tipe penelitian hukum normatif. Pendekatan yang digunakan yaitu pendekatan perundang-undangan dan perbandingan hukum (comparison approach), pendekatan filsafat hukum (philosofis approach).
\end{abstract}

Hasil Penelitian menunjukkan bahwa konstitusionalitas hak angket DPR berdasarkan original intent norma hak angket dalam naskah konprehensif perubahan Undang-Undang Dasar, hak angket hanya ditujukan kepada lembaga Negara rumpun eksekutif. Selain itu, Putusan Mahkamah Konstitusi No. 3640/PUU-XV/2017, yang mengkategorikan Komisi Pembarantasan Korupsi sebagai rumpun lembaga eksekutif adalah bertentangan dengan putusan Mahkamah Konstitusi yang lainnya, yakni Putusan Mahkamah Konstitusi Nomor 012-016-019/PUU-IV/2006, 19/PUU-V/2007, 37-39/PUU-VIII/2010. 5/PUUIX/2011, menempatkan KPK sebagai lembaga independen (independent agency) dan dikategorikan sebagai faste jurisprudence (yurisprudensi tetap). Selain itu, secara teoretis, ajaran the new theory separation of power, mengajarkan bahwa tidak tepat lagi menempatkan lembaga Negara hanya berdasarkan 3 (tiga) cabang kekuaasaan. Sedangkan konstitusionalitas hak angket DPR terhadap KPK perspektif revisi UU KPK dan perbandingan di berbagai Negara berdasarkan hasil penelitian peneliti bahwa kedudukan KPK diberbagai Negara adalah independent organt. Misalnya, di Negara Afrika Selatan, Zimbabwe, Mesir, dan Thailand. Begitu juga dengan subjek lembaga Negara yang dapat diangket, tidak terdapat diberbagai Negara yang mengalamatkan hak angket terhadap lembaga independen tersebut. Misalnya, Amerika Serikat, Filifina, Afrika selatan, yang semuanya mengalamatkan hak angket hanya lembaga Negara rumpun eksekutif.

Keywords: Hak Angket, Komisi Pemberantasan Korupsi.

\title{
A. Pendahuluan
}

Entrypoint perdebatan tentang hak angket Dewan Perwakilan Rakyat terhadap KPK bermula pada Undang-Undang No. 17 Tahun 2014 tentang MPR, 
DPR, DPD, dan DPRD Pasal 79 Ayat (3) yang mengatur sekaligus menjelaskan konsepsi apa yang dimaksud dengan hak angket, sebagai berikut $:^{4}$

Hak angket sebagaimana dimaksud pada ayat (1) huruf b adalah hak DPR untuk melakukan penyelidikan terhadap pelaksanaan suatu undang-undang dan/atau kebijakan Pemerintah yang berkaitan dengan hal penting, strategis, dan berdampak luas pada kehidupan bermasyarakat, berbangsa, dan bernegara yang diduga bertentangan dengan peraturan perundangundangan.

Dalam perkembangannya, pro dan kontra berlanjut pasca putusan Mahkamah Konstitusi No.36-40/PUU-XV/2017, yang mendudukkan KPK sebagai rumpun eksekutive organ, ${ }^{5}$ dan Mahkamah Konstitusi yang pada intinya menyebut KPK bukan merupakan objek hak angket DPR. Implikasi hukum dengan adanya putusan a quo, memaksa KPK sebagai institusi penegak hukum harus menghormati putusan Mahkamah Konstitusi dan melaksanakan putusan Mahkamah Konstitusi terkait keabsahan Panitia Khusus Angket KPK serta rekomendasi yang telah dihasilkan Pansus Angket tersebut. ${ }^{6}$ Dengan demikian, putusan tersebut menegaskan KPK merupakan lembaga yang dapat menjadi objek hak angket oleh DPR. ${ }^{7}$ Putusan Mahkamah Konstitusi a quo, dalam perkembangannya dipositivisasi pada revisi Undang-Undang KPK sebagai atavisme perdebatan posisi KPK dan sebagai rahim yang menegaskan KPK sebagai lembaga Negara yang "berkelamin” eksekutif.

Di sisi laiinnya, terdapat pula putusan Mahkamah Konstitusi yang dikategorikan oleh peneliti sebagai faste jurisprudence, yakni No.012-016019/PUU-IV/2006, No.19/PUU-V/2007, No.37-39/PUU-VIII/2010, dan No.5/PUU-IX/2011 yang mendudukkan juga KPK sebagai lembaga negara independen. Tapi, pada realitasnya, meskipun adanya putusan Mahkamah Konstitusi a quo, secara vis a vis dengan kedudukan KPK pada putusan

\footnotetext{
${ }^{4}$ Lihat Pasal 79 ayat (3) Undang-Undang Nomor 17 Tahun 2014 tentang MPR, DPR, DPD, dan DPRD

${ }^{5}$ Lihat Pertimbangan Hukum Hakim pada Pustusan Mahkamah Konstitusi Nomor 40/PUU-VX/2017.

${ }^{6}$ Novianti, "Implikasi Putusan MK Atas Penggunaan Hak Angket DPR Terhadap KPK”, Info Singkat, Vol. 10, No. 4, Februari 2018, hal. 4

${ }^{7}$ Mei Susanto, "Hak Angket DPR, KPK dan Pemberantasan Korupsi”, Integritas, Vol. 4, No. 2, Desember 2018, hal. 102.
} 
Mahkamah Konstitusi lainnya in casu, putusan Mahkamah Konstitusi No.3640/PUU-XV/2017 justru menempatkan lembaga anti rasuah tersebut, pada rumpun eksekutif dan dapat dijadikan objek hak angket oleh DPR. ${ }^{8}$

Factsheet, teori the new separation of power sebagai perkembangan teori kelembagaan Negara di dunia, mengharuskan tidak lagi untuk mendudukkan setiap lembaga Negara hanya bergantung pada 3 (tiga) cabang kekuasaan sebagaimana ajaran Trias politica ala Montesqueu yang sudah "almarhum". Di sisi lainnya, putusan Mahkamah Konstitusi dan Revisi Undang-Undang KPK, Komisi anti rasuah ini di tempatkan sebagai lembaga eksekutif. Sehingga menjadi perdebatan apakah KPK sebagai subjek yang dapat diangket, karena sebagai lembaga eksekutif ataukah KPK tidak dapat dijadikan sebagai subjek hak angket karena posisinya sebagai lembaga independent agencies?

Berdasarkan realitas tersebut, maka implikasi praktis dan akademiknya posisi KPK masih debatable dalam sistem ketatanegraan yang berdampak pada ketidakpastian terkait boleh tidaknya dilakukan angket DPR terhadap KPK kedepannya. Dari eksplikasi a quo, menarik perhatian penulis untuk melakukan penelitian dan kajian lebih lanjut terkait judul penelitian ini. Konstitusionalitas

\section{Hak Angket Dewan Perwakilan Rakyat (DPR) Terhadap Komisi}

Pemberantasan Korupsi (KPK). Berdasarkan gap penulis merumuskan fokus pembahasan pada penelitian ini sebagai berikut: 1) Konstitusionalitas Hak Angket DPR terhadap KPK; 2) Kritik Hak Angket DPR terhadap KPK Pasca Revisi UU KPK dan Perbandingannya di Berbagai Negara.

\section{B. Metode Penelitian}

Tipe penelitian ini adalah penelitian normatif dengan pendekatan penelitian filosofis, peraturan perundang-undangan, perbandingan hukum (comparison approach), dan pendekatan kasus (case approach). Sedangkan bahan hukum dalam penelitian ini adalah bahan hukum primer dan bahan hukum sekunder. Bahan hukum primer meliputi peraturan perundang-undangan (konstitusi dan undang-undang), putusan mahkamah konstitusi, dan konstitusi

${ }^{8}$ Ismail Aris, "Kedudukan KPK dalam Sistem Ketatanegaraan dalam Perspektif Teori The New Separation Of Power, (Kritik atas Putusan Mahkamah Konstitusi No. 36/PUU-XV/2017 dan No. 40/PUU-XV/2017)", Jurnal Jurisprudentie, Vol. 5 No. 2 Juni 2018, hal. 100. 
diberbagai Negara dan bahan hukum sekunder meliputi buku, jurnal penelitian hukum, serta diolah dan dianalisis secara kualitatif deskriptif.

\section{Hasil dan Pembahasan}

1. Konstitusionalitas Hak Angket DPR terhadap KPK sebuah tinjauan Kritis

\section{a. Konstitusionalitas Hak Angket DPR berdasarkan periodesasi Rezim Konstitusi}

Secara historis, hak angket bukan berasal dari pemerintahan presidensialisme. Tetapi, praktik hak angket sesungguhnya mengadopsi corak pemerintahan parlementerianisme. ${ }^{9}$ Di Indonesia, berdasarkan dari hasil rekaman beberapa pandangan the second framer of constitution perihal urgensi pengaturan hak angket dalam konstitusi. Pertama, hulunya hak angket secara historis perdebatan politik yang muncul hanya melahirkan subjek tunggal yaitu pemerintah yang bermuara pada Presiden sebagai pucuk tertinggi kekuasaan eksekutif. ${ }^{10}$ Kedua, lahirnya hak interpelasi, angket dan hak menyatakan pendapat, merupakan instrumen perimbangan kekuasaan terhadap pemerintah. Konstruksi checks and balances semata-mata dibangun atas hubungan legislatif terhadap

\footnotetext{
${ }^{9}$ Lihat pendapat Robert L Madex yang dikutip dalam Saldi Isra, Hubungan Presiden dan DPR, Jurnal Konstitusi, Vol. 10, No. 3, September 2013. hal. 507.

${ }^{10}$ Lukman Hakim Saifuddin yang menekankan secara eksplisit bahwa kewenangan DPR patut diikuti dengan beberapa hak yang patut dimiliki. Salah satunya ialah hak angket yang merupakan hak untuk melakukan penyelidikan terhadap suatu permasalahan Lukman Hakim memberikan garis penekanan bahwa fungsi ini ditujukan pada konteks pemerintah selaku pemangku kekuasaan eksekutif. Frans F. H. Matrutty juga menyampaikan bahwa hak angket merupakan instrumen pengawasan DPR terhadap pemerintah (eksekutif). Valina Singka Subekti dari Fraksi Utusan Golongan yang menyatakan hak angket dan interpelasi seyogyanya di atur dalam batang tubuh UUD. Kemudian Fraksi PDI-P yang diwakili oleh Pataniari Siahaan menyatakan secara eksplisit bahwa hak angket merupakan instrumen pengawasan DPR.Artinya DPR mengawasi jalannya pemerintahan, dengan demikian anggota DPR mempunyai hak meminta keterangan hak interpelasi, hak melakukan penyelidikan atau hak angket, hak tanya terhadap sesuatu masalah kepada Presiden. Ali Hardi Kyaidemak menyampaikan 14 butir usulan dari Fraksi PPP yang salah satu poinnya membahas tentang hak angket DPR. Khususnya pada poin ke 10, PPP mengusulkan agar DPR mempunyai instrumen pengawasan terhadap jalannya pemerintahan. Sebagaimana diusulkan bahwa DPR mempunyai hak interpelasi, hak menyatakan pendapat, hak mengajukan/persetujuan terhadap seseorang, hak penyelidikan (angket) dan hak-hak lain yang selanjutnya diatur dalam undang-undang. Slamet Efendy Yusuf dari Fraksi Golkar, dengan tegas menyatakan bahwa hilir dari hak interpelasi, angket, dan menyatakan pendapat ialah mosi ketidakpercayaan terhadap pemerintah. Efendy Yusuf berbeda pendapat dengan beberapa ahli yang telah menyatakan bahwa pengaturan hak angket tidak begitu relevan dengan sistem presidensil. Efendy Yusuf dengan tegas beranggapan bahwa tidak ada relevansi antara presidensil dengan parlementer terhadap hak angket DPR. Semua itu wajib diatur pada level konstitusi Lihat, Mahkamah Konstitusi RI, 2010, Naskah Komprehensif Perubahan UUD Negara RI Indonesia Tahun 1945; Latar Belakang, Proses, dan Hasil Pembahasan 1999-2002, Buku Ke III, Jilid 2, Jakarta: Sekretariat Jenderal MKRI, hal. 706, 709, 925, 927, 934, dan 978.
} 
eksekutif. Artinya DPR memainkan perannya sebagai cabang kekuasaan yang memiliki fungsi pengawasan terhadap jalannya pemerintahan (eksekutif). ${ }^{11}$ Ketiga lazim dipahami, jika proses hulu angket merupakan kontrol DPR terhadap eksekutif, maka hilirnya merupakan mosi tidak percaya DPR. Pada prinsipnya jenis hak DPR (interpelasi, angket, hak menyatakan pendapat) yang dijamin UUD merupakan entrypoint DPR dalam menggulingkan rezim pemerintahan atau sebagai tahapan proses impeachment terhadap Presiden dan atau Wakil Presiden.

Terlepas dari rekaman historisitas hak angket kedalam konstitusi, pada dasarnya pengaturan kewenangan hak angket DPR di setiap rezim Konstitusi Indonesia mulai dari periode naskah asli UUD 1945, Konstitusi RIS Tahun 1949, UUDS Tahun 1950, sampai dengan periode pasca amandemen UUD NRI Tahun 1945, telah diatur terkait dengan kewenangan hak angket DPR disetiap rezimnya.

Dalam perjalanan sejarah ketatanegaraan Indonesia, pengaturan kewenangan hak angket DPR berdasarkan pada Pasal 32 ayat (1) huruf b UU No. 2 Tahun 1985 tentang Perubahan Atas UU No. 16 Tahun 1969 tentang Susunan dan Kedudukan MPR, DPR, DPD, dan DPRD sebagaimana telah diubah dengan UU No. 5 Tahun 1975, dengan mengatur bahwa dapat melaksanakan fungsinya sebagaimana dimaksud dalam UUD 1945, DPR mempunyai salah satu hak yakni hak mengadakan penyelidikan. ${ }^{12}$

Berdasarkan rezim Konstitusi RIS kewenangan hak angket berdasarkan Pasal 121 mengatur bahwa Dewan Perwakilan Rakyat (DPR) mempunyai hak menyelidiki (enquete), menurut aturan-aturan yang ditetapkan dengan UndangUndang federal. ${ }^{13}$ Sedangkan berdasarkan pada periode UUDS Tahun $1950^{14}$, hak menyelidiki (enquete) DPR diatur lebih lanjut berdasarkan Undang-Undang. Berdasarkan amanat UUDS tersebut, kewenangan hak angket DPR berdasarkan

\footnotetext{
${ }^{11}$ Catatan penting dari peneliti, bahwa gerakan konstitusionalisasi hak angket DPR ke dalam Undang-Undang Dasar, bahwa secara historis tidak ada satupun perdebatan politik hukum yang muncul dan menegaskan bahwa angket dapat dialamatkan kepada cabang kekuasaan yudisial dan atau organ-organ negara independen (KY-KPU-KPK).

${ }^{12}$ Undang-Undang Republik Indonesia Nomor 2 Tahun 1985 tentang Perubahan Atas Undang-Undang Nomor 16 Tahun 1969 Tentang Susunan dan Kedudukan MPR, DPR, DPD, dan DPRD Sebagaimana Telah diubah dengan Undang-Undang Nomor 5 Tahun 1975

${ }^{13}$ Konstitusi Republik Indonesia Serikat Tahun 1949.

${ }^{14}$ Undang-Undang Dasar Sementara Tahun 1950.
} 
Pasal 70 UU No. 7 Tahun 1950 tentang Perubahan Konstitusi RIS menjadi UUDS, sebagai berikut: ${ }^{15}$ "Dewan Perwakilan Rakyat mempunyai hak menyelidiki (enquete), menurut aturan-aturan yang ditetapkan dengan undangundang".

Pasca amandemen UUD NRI Tahun 1945 yang dimulai tahun 1999-2002, dasar kewenangan hak angket berdasarkan konstitusi amandemen pada perubahan ke 2 (dua), yakni berdasarkan Pasal 20A ayat (2) UUD NRI Tahun 1945, yang mengatur bahwa dalam melaksanakan fungsinya, selain hak yang diatur dalam pasal-pasal lain undang-undang dasar ini, DPR mempunyai hak interpelasi, hak angket, dan hak menyatakan pendapat. Dengan menindaklanjuti perintah ketentuan lebih lanjut tentang hak DPR dan hak anggota DPR diatur dalam undang-undang. Dengan dasar pijakan tersebut, dibentuk UU No. 22 Tahun 2003 tentang Susunan dan Kedudukan MPR, DPR, DPD, dan DPRD sebagai produk awal terkait dengan umbrella act lembaga legislatif in casu, DPR. Berdasarkan norma itu, hak angket dipertegas Pasal 27, bahwa DPR mempunyai hak interpelasi, angket, dan menyatakan pendapat. ${ }^{16}$

Penjelasan tentang konsepsi atau definisi hak angket UU No. 22 Tahun 2003 tentang Susunan dan Kedudukan MPR, DPR, DPD, dan DPRD, UU No. 17 Tahun 2014 tentang MPR, DPR, DPD, dan DPRD ${ }^{17}$ dan Peraturan DPR No. 1 Tahun 2014 Tentang Tata Tertib ${ }^{18}$ mengkonsepsikan hak angket sebagai hak DPR untuk melakukan penyelidikan terhadap pelaksanaan suatu undang-undang dan/atau kebijakan Pemerintah yang berkaitan dengan hal penting, strategis, dan berdampak luas pada kehidupan bermasyarakat, berbangsa, dan bernegara yang

\footnotetext{
${ }^{15}$ Undang-Undang Nomor 7 Tahun 1950 tentang Perubahan Konstitusi Republik Indonesia Serikat Menjadi Undang-Undang Dasar Sementara Republik Indonesia.

${ }^{16}$ Undang-Undang Nomor 22 Tahun 2003 tentang Susunan dan Kedudukan MPR, DPR, DPD, dan DPRD

${ }^{17}$ Lihat Pasal 79 ayat (3) Undang-Undang Nomor 17 Tahun 2014 tentang MPR, DPR, DPD, dan DPRD

${ }^{18}$ Pasal 164 ayat (3) Peraturan Dewan Perwakilan Rakyat Republik Indonesia Nomor 1 Tahun 2014 Tentang Tata Tertib
} 
diduga bertentangan dengan peraturan perundang-undangan. ${ }^{19}$ Konsepsi hak angket di atas disebutkan dalam penjelasan Pasal 79 ayat $(3)^{20}:$ :Pelaksanaan suatu undang-undang dan/atau kebijakan Pemerintah dapat berupa kebijakan yang dilaksanakan sendiri oleh Presiden, Wakil Presiden, menteri negara, Panglima TNI, Kapolri, Jaksa Agung, atau pimpinan lembaga pemerintah nonkementerian". Norma a quo, menurut Mahfud MD dalam Muhammad Rinaldy Bima, dkk yang menjelaskan bahwa hak angket digunakan untuk menyelidiki pelaksanaan undang-undang atau kebijakan pemerintah. Sementara, KPK bukanlah pemerintah. ${ }^{21}$ Dengan kata lain hak angket merupakan salah satu hak kontrol DPR terhadap kebijakan eksekutif.

Berdasarkan penjelasan tersebut, menunjukkan bahwa pelaksanaan hak angket DPR di adressat-kan pada ranah lembaga eksekutif. Apabila tidak ditafsirkan demikian, menurut peneliti merupakan penghancuran makna atau mengaburkan makna pasal yang sudah jelas (interpretatio cessat in claris). Memperkuat argument peneliti bahwa dalam perjalanan sejarah terkait penggunaan hak angket oleh DPR, tidak satupun fakta menunjukkan lembaga negara yang independen di angket oleh DPR. Hal ini dapat dilihat lebih detail sebagai berikut :

Table 1 Hak Angket DPR berdasarkan Periode Rezim Pemerintahan dan Konstitusi

\begin{tabular}{|c|c|l|}
\hline \multicolumn{3}{|c|}{ Hak Angket DPR berdasarkan Periode Rezim Pemerintahan } \\
\hline $\begin{array}{c}\text { Masa } \\
\text { Pemerintahan }\end{array}$ & $\begin{array}{c}\text { Kasus yang di Angket } \\
\text { DPR }\end{array}$ & $\begin{array}{l}\text { Lembaga Negara yang } \\
\text { ditujukan Angket DPR }\end{array}$ \\
\hline Masa orde lama & $\begin{array}{c}\text { Hak Angket Penggunaan } \\
\text { Devisa }\end{array}$ & Pemerintah/Eksekutive Organ \\
\hline Masa Orde Baru & Hak Angket Pertamina & Pemerintah/Eksekutive Organ \\
\hline
\end{tabular}

\footnotetext{
${ }^{19}$ Pasal 77 ayat (3) Undang-Undang Nomor 27 Tahun 2009 tentang MPR, DPR, DPD, dan DPRD

${ }^{20}$ Undang-Undang Nomor 17 Tahun 2014 tentang Majelis Permusyawaratan Rakyat, Dewan Perwakilan Rakyat, Dewan Perwakilan Daerah, dan Dewan Perwakilan Rakyat Daerah.

${ }^{21}$ Muhammad Rinaldy Bima, et al., "Legitimasi Hak Angket Dewan Perwakilan Rakyat Terhadap Komisi Pemberantasan Korupsi”, Jurnal Kertha Patrika, Vol. 41, No. 1, April 2019, h. 29.
} 


\begin{tabular}{|c|c|c|}
\hline $\begin{array}{l}\text { Pasca Reformasi } \\
\text { Masa } \\
\text { pemerintahan } \\
\text { Abdurrahman } \\
\text { Wahid } \\
\text { 2. Masa } \\
\text { Pemerintahan } \\
\text { Megawati } \\
\text { Soekarnoputri } \\
\text { Masa } \\
\text { Pemerintahan } \\
\text { Susilo } \\
\text { Bambang } \\
\text { Yudhoyono }\end{array}$ & $\begin{array}{l}\text { 1. Hak Angket Buloggate } \\
\text { dan Bruneigate } \\
\text { 2. Hak Angket Dana } \\
\text { Nonbujeter Bulog } \\
\text { 3. Hak Angket Penjualan } \\
\text { Kapal Tanker } \\
\text { Pertamina, kasus } \\
\text { penyelesaian } \\
\text { BLBI, DPT pemilu } \\
\text { 2009, Century, }\end{array}$ & Pemerintah/Eksekutive Organ \\
\hline
\end{tabular}

\section{Sumber : Data diolah oleh peneliti}

Pada sejarah ketatanegaraan Indonesia, hak angket digunakan kali pertama pada 1950-an. Berawal dari usul resolusi RM Margono Djojohadikusumo agar DPR mengadakan angket atas usaha pemerintah memperoleh dan cara mempergunakan devisa. Panitia Angket beranggotakan 13 orang, diketuai Margono, yang tugasnya menyelidiki terkait dengan untung rugi mempertahankan devisen regime berdasar UU Pengawasan Devisen 1940 dan perubahanperubahannya. $^{22}$

Pada masa orde baru, usul penggunaan hak angket pernah muncul dalam sidang pleno DPR 7 Juli 1980. Munculnya usulan angket tersebut dilatarbelakangi oleh ketidakpuasan atas jawaban Presiden Soeharto berkenaan dengan kasus H. Thahir dan Pertamina yang disampaikan melalui Menteri Sekretaris Negara Soedarmono dalam sidang pleno DPR pada tanggal 21 Juli 1980. Jawaban tersebut disampaikan untuk menanggapi pertanyaan yang diajukan oleh beberapa anggota Fraksi Karya Pembangunan (FKP). ${ }^{23}$

Pasca reformasi hak angket pada era kepemimpinan Presiden Abdurrahman Wahid (Gus Dur) hak angket terkait dengan kasus Bulog dan

\footnotetext{
${ }^{22}$ Subardjo, "Penggunaan Hak Angket Oleh DPRRI dalam Mengawasi Kebijakan Pemerintah”, Jurnal Ilmu Hukum Novelty, Vol. 7, No. 1, Februari 2016, hal. 73

${ }^{23}$ Sunarto, "Pelaksanaan Fungsi Pengawasan DPR (Perbandingan antara Era Orde Baru dan Era Reformasi)", Integralistik, No. 1, 2018, hal. 91.
} 
sumbangan Sultan Brunei yang pada saat itu dikenal dengan nama kasus Buloggate dan Brunei gate, "yang menjerumuskan" Gus Dur pada impeachment. Pada masa pemerintahan Megawati Soekarnoputri hak angket terkait kasus Dana Nonbujeter Bulog, yakni ada kerugian negara Rp 40 miliar dalam penyelewengan dana Nonbujeter Bulog. Pada masa pemerintahan Presiden Susilo Bambang Yudhoyono (SBY) terdapat empat kasus besar yakni soal penjualan kapal tanker Pertamina, Bantuan Likuiditas Bank Indonesia (BLBI), Daftar Pemilih Tetap (DPT) Pemilu 2009, dan yang terakhir adalah kasus Bank Century. $^{24}$

Berdasarkan sejarah angket DPR di setiap periode rezim pemerintahan Indonesia di atas, jelas bahwa angket DPR hanya ditujukan kepada pihak pemerintah/eksekutive organ, tidak pernah sekalipun ditujukan kepada lembaga negara yang independen.

\section{b. Kritik Konstitusional hak angket DPR terhadap KPK pasca putusan Mahkamah Konstitusi}

Perdebatan awal terkait dengan konstitusionalitas hak angket DPR terhadap KPK pasca putusan Mahkamah Konstitusi yang menempatkan KPK dalam sistem ketatanegraan sebagai lembaga eksekutif dengan argumentasi hukum, bahwa lembaga-lembaga negara penunjang tersebut dibentuk dengan tetap berdasar pada fungsi lembaga negara utama yang menjalankan tiga fungsi: legislatif, eksekutif, dan yudikatif. Artinya, baik pada pada ranah eksekutif, legislatif, maupun yudikatif, dimungkinkan muncul lembaga penunjang untuk mendukung kompleksitas fungsi lembaga utama. Tujuan pembentukannya jelas, yakni dalam rangka efektivitas pelaksanaan kekuasaan yang menjadi tanggung jawab lembaga-lembaga utama tersebut. ${ }^{25}$

Ratio decidendi a quo, merupakan argumentasi hukum yang tidak sesuai dengan kaidah penalaran hukum, sebagaimana yang diaksentuasikan dan

\footnotetext{
${ }^{24}$ Wafia Slivi Dhesinta, 2017, "Politik Hukum Pengaturan Hak Angket dalam Sistem Pemerintahan Di Indonesia", dalam Pro Kontra Hak Angket KPK: Bunga Rampai Pemikiran Dalam Diskusi Akademik Nasional Di Fakultas Hukum Universitas Surabaya, Laboratorium Hukum Administrasi Negara Fakultas Hukum Universitas Surabaya, hal. 143-144

${ }^{25}$ Vide, pertimbangan hukum pada putusan Mahkamah Konstitusi No. 36/PUU-XV/2017. hal. 108.
} 
dielaborasi oleh E. Levi. Penalaran hukum menurut Levi, harus melalui 3 (tiga) tahapan: Pertama, melihat kesamaan antar kasus, kedua, hukum mana yang diterapkan pada kasus pertama, dan ketiga, ketentuan hukum yang dapat diaplikasikan dalam kasus kedua atau kasus lain yang serupa. ${ }^{26}$

Realitasnya, putusan Mahkamah Konstitusi No.36/PUU-XV/2017 a quo, justru menegasikan putusan Mahkamah Konstitusi terdahulu yang merupakan persoalan hukum yang sama. Misalnya, putusan Mahkamah Konstitusi No.012016-019/PUU-IV/2006, putusan Mahkamah Konstitusi No.19/PUU-V/2007, putusan Mahkamah Konstitusi No.37-39/PUU-VIII/2010, dan putusan Mahkamah Konstitusi No.5/PUU-IX/2011, yang semuanya putusan a quo, menempatkan Komisi Pemberantasan Korupsi (KPK) sebagai lembaga independen (independent agency). A fortiori, menurut peneliti, bahwa putusan Mahkamah Konstitusi a quo yang mendudukkan KPK sebagai independent agency merupakan putusan faste jurisprudence (yurisprudensi tetap). Oleh karenanya, seharusnya putusan terdahulu secara mutatis mutandis berlaku pada saat DPR melakukan hak angket terhadap KPK. Selain itu, konsekuensi putusan Mahkamah Konstitusi yang final and binding harus ditafsirkan putusan Mahkamah Konstitusi yang terbaru tidak boleh menyimpangi putusan Mahkamah Konstitusi sebelumnya.

Eksplikasi tersebut menunjukkan bahwa master mind argumentasi penalaran hukum putusan Mahkamah Konstitusi dalam fondasi filosofis juga tidak tepat lagi mengotak-ngotakkan suatu lembaga negara kedalam teori separation of power atau trias politika milik Montesquie. Hal itu, inherent dengan pendapat Jimly Ashiddiqie, yang melakukan kritik doktrin trias politika khas Montesquie, dengan argumentasi juga yang menyatakan bahwa $:^{27}$

"Konsepsi trias politica yang diidealkan oleh Montesquieu ini jelas tidak relevan lagi dewasa ini, mengingat tidak mungkin lagi mempertahankan bahwa ketiga organisasi tersebut hanya berurusan secara eksklusif dengan salah satu dari ketiga fungsi kekuasaan tersebut. Kenyataan dewasa menunjukkan bahwa hubungan antar cabang kekuasaan itu tidak mungkin tidak saling bersentuhan, dan bahkan ketiganya bersifat sederajat dan

\footnotetext{
${ }^{26}$ Urbanus Ura Weruin, Logika, Penalaran, dan Argumentasi Hukum, Jurnal Konstitusi, Vol. 14, No. 2, Juni 2017. hal. 384.

${ }^{27}$ Jimly Ashiddiqie, 2006, Perkembangan dan Konsolidasi Lembaga Negara Pasca Reformasi, Sekretariat Jenderal dan Kepaniteraan Mahkamah Konstitusi RI, Jakarta, hal. 35.
} 
saling mengendalikan satu sama lain sesuai dengan prinsip checks and balances".

Pendapat Jimly di atas memiliki relevansi dengan gagasan the new separation of power yang di elaboraasi oleh Bruce Ackerman ${ }^{28}$ sebagai avant garde (perintis) teori the new separation of power-nya, yang pada pokoknya di sistem ketatanegaraan Amerika telah bergeser dari trias politica yang ditandai kelahiran lembaga independen dan di Marika terdapat 5 Cabang kekuaasaan yakni House, Senate, President, Court, and independent agencies such as the Federal Reserve Board. Bahkan lebih ekstrem lagi, pendapat Cindy Skach bahwa terdapat 6 cabang kekuasaan, yakni: DPR, senat, President as head of state, Prime Minister as head of executive, Yudikatif, dan Independent Agencies. ${ }^{29}$

Dengan demikian bahwa, argumentasi Mahkamah Konstitusi sebagaimana dalam ratio decidendi-nya berbendapat bahwa tujuan pembentukannya (pembentukan lembaga independen) jelas, yakni dalam rangka efektivitas pelaksanaan kekuasaan yang menjadi tanggung jawab lembaga-lembaga utama. ${ }^{30}$ Argumentasi demikian merupakan fallacy, karena pembentukan lembaga independen seperti Komisi Penyiaran Indonesia (KPI), Komisi Yudisial (KY), Komisi Pemilihan Umum (KPU), Komisi Nasional Hak Asasi Manusia (Komnas HAM), tidak tepat "dijerumuskan" sebagai lembaga negara eksekutif, atau legislatif, dan yudikatif. Jika pertimbangan hukum sebagaimana diatas yang harus diikuti, maka akan terjadi konflik ketatanegaraan kedepannya dan lembaga negara independen tersebut nyaris juga kedepannya dilakukan hak angket. Padahal lembaga negara tersebut meskipun bersifat menunjang, tetapi tidak rasional jika harus dipaksakan masuk dan dikategorikan sebagai salah satu dari tiga cabang kekuasaan seperti doktrin trias politica. Lagi pula, dalam praktik ketatanegaraan dan berdasarkan konstitusi di dunia ini tidak satupun negara menempatkan electoral commission dan Komnas HAM, serta Komisi Penyiaran Indonesia selain

\footnotetext{
${ }^{28}$ Bruce Ackerman, The New Separation of Powers, Journal Harvard Law Review Vol. 113, Januari Tahun 2000, hal. 724. Vide to avalaible at http://abdet.com.br/site/wpcontent/uploads/2014/11/The-New-Separation-of-Powers.pdf.

${ }^{29}$ Cindy Skach, The "newest " Separation of Powers: Emipresidentialism, Journal ICON, Vol. 5, No 1, 2007, hal. 117-119. hal. 108 .

${ }^{30}$ Vide, pertimbangan hukum pada putusan Mahkamah Konstitusi No. 36/PUU-XV/2017.
} 
lembaga negara berbentuk independent agencies.

Logika putusan Mahkamah Konstitusi a quo, mendudukkan lembaga negara independen yang sama dengan komisi negara biasa yang bersifat penunjang, seperti Komisi Polisi Nasional dan Komisi Kejaksaan. Padahal hal itu justru berbeda dengan komisi negara biasa (state commissions). Untuk memperkuat argumentasi a quo, peneliti dengan merujuk argumentasi Michael R. Asimow, komisi negara biasa hanyalah bagian dari eksekutif dan tidak mempunyai peran yang terlalu penting. ${ }^{31}$ Misalnya, Komisi Polisi Nasional (Kompolnas) dan Komisi Kejaksaan. Argumentasinya, pembentukan komisi tersebut dibentuk berdasarkan pemberian delegasi kepada Kejaksaan dan Kepolisian untuk membentuk komisi tersebut dan pembentukannya melalui undang-undang. Dengan demikian, konstitusionalitas hak angket DPR terhadap KPK pasca putusan Mahkamah Konstitusi tidak memiliki pijakan filosofis, argument teoretis dan praktik ketatanegaraan.

\section{Konstitusionalitas Hak Angket DPR terhadap KPK Perspektif Revisi}

\section{UU KPK dan Perbandingan di Berbagai Negara}

Entry point perdebatan KPK sebagai rumpun eksekutif, pasca adanya putusan Mahkamah Konstitusi No. 40/PUU-XV/2017, yang mendudukkan KPK sebagai rumpun eksekutive organ yang kedudukannya sama dengan Lembaga Kejaksaan. Dalam ratio legis-nya, Mahkamah Konstitusi berpendapat bahwa oleh karena KPK merupakan lembaga yang berada di ranah eksekutif yang melaksanakan tugas penyelidikan, penyidikan, penuntutan dalam perkara tindak pidana korupsi yang sejatinya merupakan kewenangan Kepolisian dan/atau Kejaksaan, bahkan dengan mengingat fungsi KPK sebagai lembaga khusus untuk mendorong agar pemberantasan korupsi dapat berjalan secara efektif, efisien, dan optimal, maka dapat disimpulkan dengan sendirinya bahwa KPK dapat menjadi objek dari hak angket DPR dalam fungsi pengawasannya. Dengan demikian, dalam melaksanakan fungsi pengawasannya, DPR dapat menggunakan hak konstitusionalnya termasuk hak angket terhadap KPK hanya terbatas pada hal-hal

\footnotetext{
${ }^{31}$ Pendapat Asimow dikutip dalam, Ismail Aris, "Kedudukan KPK dalam Sistem Ketatanegaraan dalam Perspektif Teori The New Separation Of Power (Kritik atas Putusan Mahkamah Konstitusi No. 36/PUU-XV/2017 dan No. 40/PUU-XV/2017)”, hal. 105
} 
yang berkaitan dengan pelaksanaan tugas dan kewenangan KPK, selain pelaksanaan tugas dan kewenangan yang berkaitan dengan tugas dan kewenangan yudisialnya (penyelidikan, penyidikan, dan penuntutan). ${ }^{32}$

Berdasarkan ratio legis putusan di atas a quo berimplikasi pada kebolehan DPR untuk mengalamatkan hak angket terhadap KPK. Hal itu, menurut peneliti bahwa pertimbangan tersebut adalah penalaran hukum yang keliru, karena hakim Mahkamah Konstitusi dalam merumuskan suatu putusan tidak melihat dan mempertimbangkan sejarah hak angket di Indonesia sebagaimana yang telah diuraikan sebelumnya, hak angket diberbagai negara ${ }^{33}$ dan kedudukan komisi anti korupsi diberbagai negara yang akan dijelaskan diuraian selanjutnya. Putusan Mahkamah Konstitusi tersebut, dikuatkan dengan Revisi Undang-Undang KPK, bahwa kedudukan Komisi Pemberantasan Tindak Pidana Korupsi yang selanjutnya disebut Komisi Pemberantasan Korupsi adalah lembaga negara dalam rumpun kekuasaan eksekutif yang melaksanakan tugas pencegahan dan pemberantasan Tindak Pidana Korupsi sesuai dengan Undang-Undang ini. ${ }^{34}$

Konsekuensi logis kedudukan KPK sebagai rumpun lembaga eksekutif, berimplikasi pada KPK wajib membuat laporan pertanggungjawaban 1 (satu) kali dalam 1 (satu) tahun kepada Presiden Republik Indonesia, Dewan Perwakilan Rakyat, dan Badan Pemeriksa Keuangan. ${ }^{35}$ Konsekuensi lainnya KPK sebagai lembaga negara eksekutif juga berimplikasi pada pegawai KPK sebagai aparatur sipil negara (ASN) sesuai dengan ketentuan peraturan perundang-undangan mengenai ASN." 36 Norma a quo, merupakan political revenge (politik balas dendam) dari DPR terhadap KPK. Argumen peneliti dikuatkan berdasarkan data sebagai berikut :

\footnotetext{
${ }^{32}$ Putusan Mahkamah Konstitusi Republik Indonesia Nomor 40/PUU-XV/2017.

${ }^{33}$ Ulasan hak angket diberbagai negara. Vide pada table 2.

${ }^{34}$ Vide, Pasal 1 angka 3 dan Pasal 3. Rancangan Undang-Undang Tentang Komisi Pemberantasan Tindak Pidana Korupsi yang telah disetujui serta belum disahkan dan dibukukan ke lembaran negara.

${ }^{35}$ Vide, Pasal 7 Ayat (2) dan Pasal 15 Rancangan Undang-Undang Tentang Komisi Pemberantasan Tindak Pidana Korupsi yang telah disetujui serta belum disahkan dan dibukukan ke lembaran negara.

${ }^{36}$ Pasal 1 Angka 6. Rancangan Undang-Undang Tentang Komisi Pemberantasan Tindak Pidana Korupsi yang telah disetujui serta belum disahkan dan dibukukan ke lembaran negara.
} 


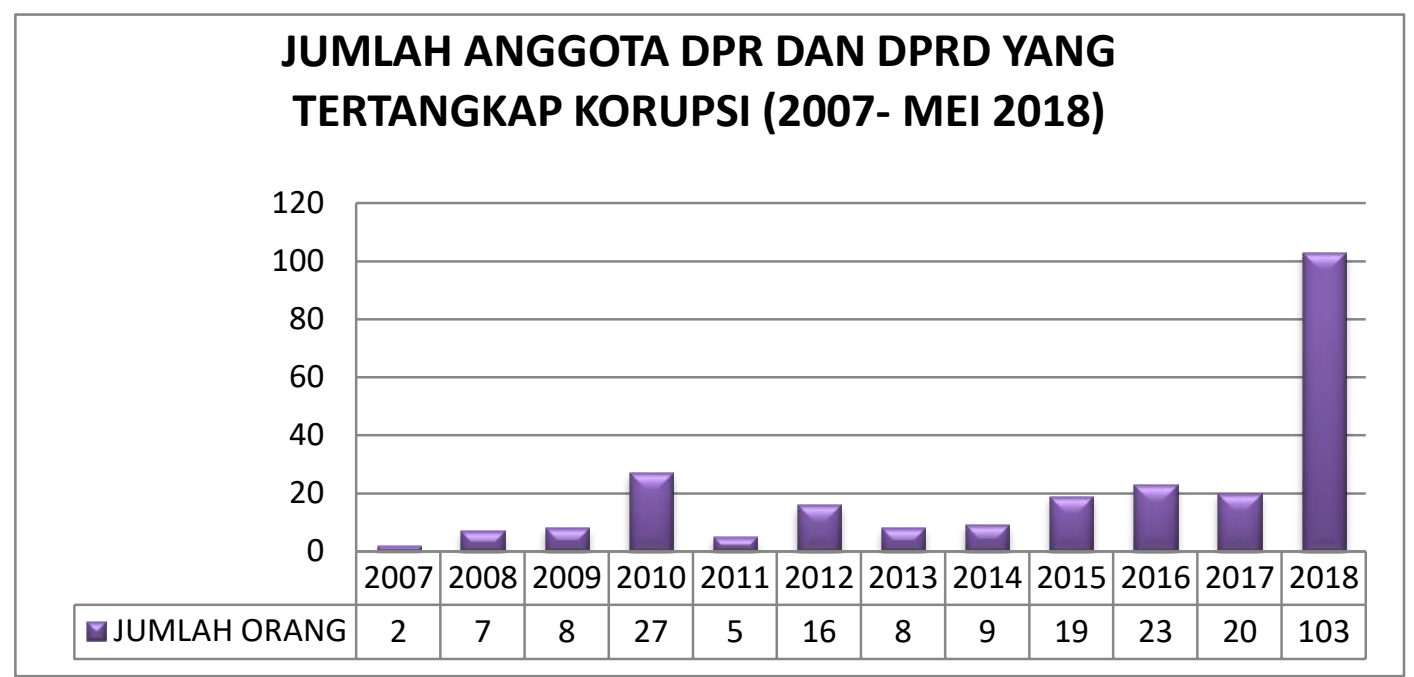

Sumber : Diolah dari data Komisi Pemberantasan Korupsi (KPK), $2018^{37}$.

Data di atas menunjukkan bahwa dalam termin waktu 11 (sebelas) tahun, jumlah politisi yang telah tertangkap adalah berjumlah 247 orang. Bahkan tingkat korupsi yang dilakukan oleh politisi paling tertinggi pada tahun 2018 yakni sebanyak 103 orang. Hal itu menunjukkan bahwa revisi undang-undang KPK tidak terlepas dari hidden politicall intention (kepentingan politik yang terselubung) dari politisi di DPR sebagai bentuk feedback terhadap komisi anti rasuah. Selain itu, implikasi konstitusional terhadap KPK sebagai lembaga negara berbentuk eksekutif adalah KPK sebagai objek hak angket dari DPR. Hal itulah menurut UNCAC coalition ${ }^{38}$, amendments to the KPK law, which endanger the anti-corruption agency's independence and undermine its ability to effectively prevent, investigate and prosecute corruption (amandemen UU KPK baru-baru ini, yang membahayakan independensi lembaga anti-korupsi dan merusak kemampuannya untuk secara efektif mencegah, menyelidiki dan menuntut korupsi). Padahal, jika mengkomparasikan dengan lembaga komisi anti rasuah diberbagai Negara, kedudukan KPK adalah sebagai independent organ, sebagaimana eksplikasi table di bawah ini :

\footnotetext{
${ }^{37}$ https://acch.kpk.go.id/id/statistik/tindak-pidana-korupsi/tpk-berdasarkan-profesijabatan.

${ }^{38} \mathrm{UNCAC}$ Coalition, UNCAC Coalition Statement on threats to the independence of Indonesia's Corruption Eradication Commission KPK, 27.09.2019. https://uncaccoalition.org/wpcontent/uploads/Indonesia-statement-on-KPK-\%E2\%80\%93-27092019.pdf
} 
Tabel 3 Kedudukan Lembaga Anti Korupsi di Berbagai Negara

\begin{tabular}{|c|c|c|c|}
\hline Negara & $\begin{array}{c}\text { Lembaga Anti } \\
\text { Korupsi }\end{array}$ & $\begin{array}{c}\text { Bentuk } \\
\text { Lembaga }\end{array}$ & Dasar Pembentukan \\
\hline Thailand & $\begin{array}{c}\text { NCCC (National } \\
\text { Counter Corruption } \\
\text { Commission }\end{array}$ & $\begin{array}{c}\text { Independent } \\
\text { Agencies }\end{array}$ & $\begin{array}{c}\text { Thailand's } \\
\text { Constitution of } 2014\end{array}$ \\
\hline Zimbabwe & $\begin{array}{c}\text { The Zimbabwe Anti- } \\
\text { Corruption } \\
\text { Commission } \\
\text { Mesir }\end{array}$ & $\begin{array}{c}\text { Independent } \\
\text { Agencies }\end{array}$ & $\begin{array}{c}\text { Zimbabwe's } \\
\text { Constitution of } 2013\end{array}$ \\
\hline Afrika & $\begin{array}{c}\text { National Anti- } \\
\text { Corruption }\end{array}$ & $\begin{array}{c}\text { Independent } \\
\text { Agencies }\end{array}$ & $\begin{array}{c}\text { Egypt's Constitution } \\
\text { of 2014 }\end{array}$ \\
\hline Corraption Forum & Andendent & $\begin{array}{c}\text { Corruption Act } \\
\text { (Undang-Undang } \\
\text { Anti Korupsi) }\end{array}$ \\
\hline
\end{tabular}

\section{Sumber : Diolah dari Konstitusi masing-masing negara tersebut}

Kedudukan komisi anti korupsi di negara Thailand, dapat dilihat pada Section 20 ayat (6), berdasarkan Amandemen Konstitusi Tahun 2014 di Thailand, yang pada pokoknya bahwa komisi anti korupsi di Thailand sebagai lembaga independen dan bebas dari kontrol kepala eksekutif (presiden/perdana menteri). ${ }^{39}$ Sedangkan komisi anti korupsi Zimbabwe yang menempatkan komisi anti korupsinya sebagai lembaga negara independen. Komisi anti korupsi a quo The Zimbabwe Anti-Corruption Commission (ZACC) is an independent commission created to combat corruption and crime. It is established in terms of Chapter 13, Part 1 of the Zimbabwe's Constitution of 2013. ${ }^{40}$

A fortiori di Mesir dan Afrika Selatan juga memiliki komisi anti korupsi yang ditempatkan pada independent organ, sebagaimana yang tertuang pada Egypt's Constitution of 2014 Article 218 section eleven (sebelas) dalam subsection

${ }^{39}$ Independensi komisi anti rasuah di Thailand dapat dilihat lebih detail pada ketentuan konstitusinya sebagai berikut : The Prime Minister and Minister shall have the qualifications and not being under the prohibitions as follows: not being a judge of the Constitutional Court, a judge of any Court, a State Attorney, a commissioner of the Election Commission, an Ombudsman, a commissioner of the National Counter Corruption Commission, a commissioner of the State Audit Commission, the Auditor-General or a member of the Human Rights Commission. Vide, Thailand's Constitution of 2014, constituteproject.org. Diakses pada tanggal 22 Februari 2018.

${ }^{40}$ Zimbabwe's Constitution of 2013. Avalaible at https://www.constituteproject.org/ constitution/Zimbabwe_2013.pdf. Diakses pada tanggal 2 Oktober 2019 
two tentang Independent bodiest and regulatory Agencies. Hal tersebut berdasarkan, sebagai berikut: The state is committed to fighting corruption, and the competent control bodies and organizations are identified by law... (Negara berkomitmen untuk memerangi korupsi dan lembaga kontrol yang berkompoten dibentuk berdasarkan undang-undang. ${ }^{41}$

Komisi anti korupsi di Afrika Selatan, diatur berdasarkan Anti Corruption Act pada Chapter 1 pada angka 7. Pada Chapter tersebut kedudukan komisi anti korupsi juga sebagai independent organ. Lebih detailnya sebagai berikut : Independence of the Anti-Corruption Unit The Anti Corruption Unit: (1) Is independent and subject only to the Constitution and the law;; (2) Must be impartial and perform its functions without fear, favour or prejudice; and (3) Required to submit reports four times a year to Parliament. ${ }^{42}$

Berdasarkan uraian a quo, menunjukkan fakta sistem ketatanegaraan bahwa kedudukan komisi anti korupsi di negara Thailand, Zimbabwe, Mesir dan Afrika Selatan, ditempatkan sebagai lembaga negara independen/independent organ. Memperkuat dalil peneliti, dengan mengutip hasil penelitian yang diteliti oleh Denny Indrayana bahwa terdapat 63 negara memiliki lembaga anti rasuah yang berbentuk independen organt ${ }^{43}$. A fortiori, bentuk penguatan KPK sebagai lembaga independen diberbagai Negara, dasar pembentukan lembaga a quo, berdasarkan konstitusi dan terdapat 30 negara. ${ }^{44}$ Hal itu menunjukkan bahwa revisi undang-undang yang melembagakan KPK sebagai lembaga eksekutif adalah terbantah secara a priori dan a posteriori.

Selain itu, hak angket lembaga perwakilan rakyat dibeberapa negara yang hanya berwenang untuk mengangket kepada eksekutive organ. Hal itu, diperkuat dengan hasil penelusuran peneliti di berbagai Negara sebagaimana uraian pada tabel berikut ini:

\footnotetext{
${ }^{41}$ Egypt's Constitution of 2014. Avalaible at https://www.constituteproject.org/ constitu tion/Egypt_2014.pdf. Diakses pada tanggal 2 Oktober 2019.

${ }^{42}$ Ismail Aris, "Kedudukan KPK dalam Sistem Ketatanegaraan dalam Perspektif Teori The New Separation Of Power (Kritik atas Putusan Mahkamah Konstitusi No. 36/PUU-XV/2017 dan No. 40/PUU-XV/2017)", h. 106

${ }^{43}$ Denny Indrayana, Jangan Bunuh KPK, (Malang: Intrans Publishing, 2016), hal. 75.

${ }^{44}$ Ibid, hal. 82.
} 
Tabel 2 Hak Angket Legislatif di Berbagai Negara

\begin{tabular}{|c|c|c|c|}
\hline Negara & $\begin{array}{l}\text { Nama Lembaga } \\
\text { Perwakilan } \\
\text { Rakyat }\end{array}$ & $\begin{array}{l}\text { Dasar Kewenangan } \\
\text { Hak Angket }\end{array}$ & $\begin{array}{l}\text { Lembaga Negara } \\
\text { yang diangket }\end{array}$ \\
\hline $\begin{array}{l}\text { Amerika } \\
\text { Serikat }\end{array}$ & $\begin{array}{l}\text { United States } \\
\text { House of } \\
\text { Representatives } \\
\text { (congress) dan } \\
\text { Senate }\end{array}$ & $\begin{array}{c}\text { United States of } \\
\text { America's } \\
\text { Constitution of } 1789 \\
\text { with Amendments } \\
\text { through } 1992\end{array}$ & Eksekutive Organ \\
\hline Filipina & $\begin{array}{c}\text { Senate and a } \\
\text { House of } \\
\text { Representatives }\end{array}$ & $\begin{array}{c}\text { The } 1987 \\
\text { Constitution of The } \\
\text { Republic of The } \\
\text { Philippines }\end{array}$ & Eksekutive Organ \\
\hline $\begin{array}{l}\text { Afrika } \\
\text { Selatan }\end{array}$ & $\begin{array}{l}\text { the National } \\
\text { Assembly, and } \\
\text { the National } \\
\text { Council of } \\
\text { Provinces }\end{array}$ & $\begin{array}{l}\text { Constitution of The } \\
\text { Republic of South } \\
\text { Africa No. } 108 \text { of } \\
1996\end{array}$ & Eksekutive Organ \\
\hline
\end{tabular}

\section{Sumber : Diolah berdasarkan Konstitusi Negara Tersebut}

Negara Amerika Serikat, hak angket pada lembaga perwakilan rakyat hanya ditujukan kepada lembaga eksekutif. Hak tersebut dikenal dengan istilah congressional oversight terhadap cabang kekuasaan eksekutif (pemerintah, termasuk badan-badan federal) sebagai bagian dari investigation power yang dimiliki oleh Kongres. Meskipun, hal itu tidak secara eksplisit diatur dalam Konstitusi Amerika Serikat, melainkan hanya secara implisit. Namun demikian, hak ini (congressional oversight) mencakup aspek yang sangat luas, yaitu meninjau, memonitor, dan mensupervisi implementasi kebijakan publik. ${ }^{45}$

Institusionalisasi congressional oversight di Amerika Serikat menurut Matthew Mantel dengan mengutip putusan Watkins vs. United States, 354 U.S. 178, 187 (1957), dengan menyatakan bahwa limitasi hak angket di Amerika tidak berkenaan dengan penegakan hukum dengan menyatakan nor is the Congress a law enforcement or trial agency. These are functions of the executive and judicial

\footnotetext{
${ }^{45}$ Putusan Mahkmah Konstitusi Nomor 36/PUU-XV/2017
} 
departments of government. ${ }^{46}$ Dari sinyalemen a quo, pada prinsipnya bahwa di Amerika, hak angket yang dimiliki oleh kongres tidak mengangket terkait penegak hukum atau berkenaan dengan fungsi dibidang kekuaasaan kehakiman yang merupakan relasi fungsi eksekutif dan yudikatif.

Negara Filipina, konstitusionalisasi hak angket terdapat pada the Constitution of The Republic of The Philippines 1987 berdasarkan pada Article VI (enam) Section 21 dan 22 yang mengatur sebagai berikut : The Senate or the House of Representatives or any of its respective committees may conduct inquiries ${ }^{47}$....(Senat atau Dewan Perwakilan Rakyat atau salah satu komite masing-masing dapat melakukan penyelidikan). Sedangkan subjek yang diadressatkan adalah lembaga eksekutif. Hal itu di berdasarkan Section 22. The heads of departments may, upon their own initiative, with the consent of the President, or upon the request of either House, as the rules of each House shall provide, appear before and be heard by such House on any matter pertaining to their departments. Written questions shall be submitted to the President of the Senate or the Speaker of the House of Representatives at least three days before their scheduled appearance. ${ }^{48}$

Dari norma tersebut, menunjukkan bahwa di Negara Filipina hak angket hanya ditujukan kepada lembaga eksekutif. Selain di Negara Filifina, landasan konstitusional hak angket di Afrika Selatan, di atur pada Constitution of The Republic of South Africa No. 108 of 1996, bahwa fungsi parlemen di Afrika Selatan salah satunya adalah hak angket (keep oversight of the executive and organs of state) baik terhadap pemerintah pusat maupun pemerinrah lokal.

Di Afrika Selatan hak angket juga memakai istilah yang sama dengan Amerika yakni memakai istilah oversight. Istilah itu didefinisikan sebagai $a$

\footnotetext{
${ }^{46}$ Matthew Mantel, Congressional Investigations: A Bibliography, Law Library Journal, Vol. 100 (2), 2008. hal. 328. https://www.academia.edu/7346149/Congressional_Investigations A Bibliography

${ }^{47}$ The 1987 Constitution of The Republic of The Philippines. Avalaible at https:// www.constituteproject.org/constitution/Philippines_1987.pdf?lang=en. Diakses pada tanggal 2 Oktober 2019

${ }^{48}$ The 1987 Constitution of The Republic of The Philippines. https://www. constituteproject.org/constitution/Philippines_1987.pdf?lang=en. Diakses pada tanggal 2 Oktober 2019
} 
function granted by the Constitution to Parliament to monitor and oversee government actions. Artinya, bahwa hak angket sebagai fungsi mengawasi tindakan pemerintah (eksekutif). Fokus hak angket terkait dengan implementation of laws, application of budgets, strict observance of laws of Parliament and the Constitution, effective management of government departments. ${ }^{49} \mathrm{Hal}$ itu juga memiliki relevansi berdasarkan Article 55, Constitution of The Republic of South Africa No. 108 of 1996. Bahwa Powers of National Assembly : ${ }^{50}$ (2) The National Assembly must provide for mechanisms : (a) to ensure that all executive organs of state in the national sphere of government are accountable to it; and (b) to maintain oxmight of the exerciqe of national executive authority, including the implementation of legislation.

Praktik hak angket diberbagai Negara memiliki relevansi dengan pendapat Hiromori Yamamoto, yang mengeksplikasikan hasil penelitiannya yang telah meneliti 88 parlemen yang ada di dunia, dengan menyatakan bahwa congressional oversight, atau inquiry sendiri adalah the review, monitoring and supervision of government and public agencies, including the implementation of policy and legislation. ${ }^{51}$ Artinya bahwa hak angket sebagai bentuk peninjauan ulang, pemantauan, dan supervisi pemerintah dan lembaga publik, yang meliputi implementasi kebijakan dan juga undang-undang yang dilakukan oleh lembaga parlemen.

Terlepas dari jenis hak angket sebagaimana uraian di atas, pada prinsipnya hak angket diberbagai Negara menunjukkan bahwa lembaga perwakilan rakyat

\footnotetext{
${ }^{49}$ Vide, https://www.parliament.gov.za/what-parliament-does
}

${ }^{50}$ Constitution of The Republic of South Africa No. 108 of 1996. Avalaible at https://www.gov.za/sites/default/files/images/a108-96.pdf. Diakses pada tanggal 2 Oktober 2019.

${ }^{51}$ Hiromori Yamamoto, Tools For Parliamentary Oversight A Comparative Study of 88 National Parliaments, Inter-Parliamentary Union, Switzerland, 2007. Avalaible at http://archive.ipu.org/PDF/publications/oversight08-e.pdf. Bandingkan dengan pendapat Arifin Sari Surnganlan Tambunan, terdapat 4 (empat) jenis hak angket, yaitu hak angket dalam bidang keuangan (financial enquete), hak angket di bidang legislatif (legislative enquete), hak angket di bidang politik (political enquete) dan angket soal pemilihan umum (election enquete). Vide, Arifin, S.S.T. 1998. Fungsi Dewan Perwakilan Rakyat Republik Indonesia Menurut UUD 1945, Suatu Studi Analisis Mengenai Pengaturannya Tahun 1966-1997. Jakarta: Sekolah Tinggi Hukum Militer. hal. 158-159. 
dimasing-masing negara dalam melaksanakan hak angketnya, hanya ditujukan kepada pemerintah/eksekutive organ. Hal itu secara expressive verbis, bahwa hak angket tidak ditujukan selain eksekutive organ. Praktik yang tidak lazim dijumpai jika hak angket diadressatkan kepada lembaga komisi anti rasuah yang sudah jelas kedudukannya berada pada independent organ.

\section{Kesimpulan}

Berdasarkan dari hasil dan pembahasan di atas, peneliti menyimpulkan sebagai berikut : pertama; bahwa konstitusionalitas hak angket DPR berdasarkan original intent norma hak angket dalam naskah konprehensif perubahan UndangUndang Dasar, hak angket hanya ditujukan kepada lembaga Negara rumpun eksekutif. Selain itu, Putusan Mahmakah Konstitusi yang mengkategorikan KPK sebagai rumpun lembaga eksekutif adalah bertentangan dengan putusan Mahkamah Konstitusi yang lainnya, yakni Putusan Mahkamah Konstitusi No.012016-019/PUU-IV/2006, 19/PUU-V/2007, 37-39/PUU-VIII/2010. 5/PUU-IX/2011, menempatkan KPK sebagai lembaga independen (independent agency) dan dikategorikan sebagai faste jurisprudence (yurisprudensi tetap). Selain itu, secara teoretis, the new theory separation of power, mengajarkan bahwa tidak tepat lagi menempatkan lembaga Negara hanya berdasarkan 3 (tiga) cabang kekuaasaan. Kedua; bahwa konstitusionalitas hak angket DPR terhadap KPK perspektif revisi UU KPK dan perbandingan di berbagai Negara berdasarkan hasil penelitian peneliti bahwa kedudukan KPK diberbagai Negara adalah independent organt. Misalnya, di Negara Afrika Selatan, Zimbabwe, Mesir, dan Thailand. Begitu juga dengan subjek lembaga Negara yang dapat diangket, tidak terdapat diberbagai Negara yang mengalamatkan hak angket terhadap lembaga independen tersebut. Misalnya, Amerika Serikat, Filifina, Afrika selatan, yang semuanya mengalamatkan hak angket hanya lembaga Negara rumpun eksekutif.

\section{DAFTAR PUSTAKA}

\section{Buku-buku}

Ashiddiqie, Jimly, 2006, Perkembangan dan Konsolidasi Lembaga Negara Pasca Reformasi, Sekretariat Jenderal dan Kepaniteraan Mahkamah Konstitusi RI, Jakarta, 
Dhesinta, Wafia Slivi, 2017, "Politik Hukum Pengaturan Hak Angket dalam Sistem Pemerintahan Di Indonesia", dalam Pro Kontra Hak Angket KPK: Bunga Rampai Pemikiran Dalam Diskusi Akademik Nasional Di Fakultas Hukum Universitas Surabaya, Laboratorium Hukum Administrasi Negara Fakultas Hukum Universitas Surabaya.

Indrayana, Denny, 2016, Jangan Bunuh KPK, Intrans Publishing, Malang .

Mahkamah Konstitusi RI, 2010, Naskah Komprehensif Perubahan UUD Negara RI Indonesia Tahun 1945; Latar Belakang, Proses, dan Hasil Pembahasan 1999-2002, Buku Ke III, Jilid 2, Sekretariat Jenderal MKRI, Jakarta.

S.S.T, Arifin, 1998. Fungsi Dewan Perwakilan Rakyat Republik Indonesia Menurut UUD 1945, Suatu Studi Analisis Mengenai Pengaturannya Tahun 1966-1997. Sekolah Tinggi Hukum Militer. Jakarta

Yamamoto, Hiromori, 2007, Tools For Parliamentary Oversight A Comparative Study of 88 National Parliaments, Inter-Parliamentary Union, Switzerland, .Avalaible at http://archive.ipu.org/PDF/publications/oversight08-e.pdf.

\section{Jurnal}

Ackerman, Bruce, “The New Separation of Powers", Harvard Law Review Vol. 113, Januari 2000.

Aris, Ismail, "Kedudukan KPK dalam Sistem Ketatanegaraan dalam Perspektif Teori The New Separation Of Power, (Kritik atas Putusan Mahkamah Konstitusi No. 36/PUU-XV/2017 dan No. 40/PUU-XV/2017)", Jurnal Jurisprudentie, Vol. 5 No. 2 Juni 2018.

Bima, Muhammad Rinaldy, et al., "Legitimasi Hak Angket Dewan Perwakilan Rakyat Terhadap Komisi Pemberantasan Korupsi”, Jurnal Kertha Patrika, Vol. 41, No. 1, April 2019.

Isra, Saldi, "Hubungan Presiden dan DPR", Jurnal Konstitusi, Vol. 10, No. 3, September 2013.

Mantel, Matthew, "Congressional Investigations: A Bibliography", Law Library Journal, Vol. 100 (2), 2008. https://www.academia.edu/7346149/ Congressional_Investigations_A_Bibliography.

Novianti, "Implikasi Putusan MK Atas Penggunaan Hak Angket DPR Terhadap KPK”, Info Singkat, Vol. 10, No. 4, Februari 2018.

Skach, Cindy, The "newest" Separation of Powers: Emipresidentialism, Journal I-CON, Vol. 5, No. 1, 2007.

Subardjo, "Penggunaan Hak Angket Oleh DPR RI dalam Mengawasi Kebijakan Pemerintah", Jurnal Ilmu Hukum Novelty, Vol. 7, No. 1, Februari 2016.

Sunarto, "Pelaksanaan Fungsi Pengawasan DPR (Perbandingan antara Era Orde Baru dan Era Reformasi)”, Integralistik, No. 1, 2018.

Susanto, Mei "Hak Angket DPR, KPK dan Pemberantasan Korupsi", Integritas, Vol. 4, No. 2, Desember 2018. 
Weruin, Urbanus Ura, "Logika, Penalaran, dan Argumentasi Hukum", Jurnal Konstitusi, Vol. 14, No. 2, Juni 2017.

\section{Peraturan Perundang-undangan dan Putusan Mahkamah Konstitusi}

Undang-Undang Dasar Negara Republik Indonesia Tahun 1945

Konstirusi Republik Indonesia Serikat Tahun 1949

Undang-Undang Dasar Sementara Tahun 1950.

Undang-Undang Nomor 7 Tahun 1950 tentang Perubahan Konstitusi Republik Indonesia Serikat Menjadi Undang-Undang Dasar Sementara Republik Indonesia.

Undang-Undang Republik Indonesia Nomor 2 Tahun 1985 tentang Perubahan Atas Undang-Undang Nomor 16 Tahun 1969 Tentang Susunan dan Kedudukan MPR, DPR, DPD, dan DPRD Sebagaimana Telah diubah dengan Undang-Undang Nomor 5 Tahun 1975. (Lembaran Negara Republik Indonesia Tahun 1987 Nomor 2, Tambahan Lembaran Negara Nomor 3282)

Undang-Undang Nomor 30 Tahun 2002 tentang Komisi Pemberantasan Tindak Pidana Korupsi. (Lembaran Negera Republik Indonesia Tahun 2002 Nomor 137, Tambahan Lembaran Negara Republik Indonesia Nomor 4250)

Undang-Undang Nomor 22 Tahun 2003 tentang Susunan dan Kedudukan MPR, DPR, DPD, dan DPRD. (Lembaran Negera Republik Indonesia Tahun 2003 Nomor 92, Tambahan Lembaran Negara Republik Indonesia Nomor 4310)

Undang-Undang Nomor 27 Tahun 2009 tentang MPR, DPR, DPD, dan DPRD. (Lembaran Negera Republik Indonesia Tahun 2009 Nomor 123, Tambahan Lembaran Negara Republik Indonesia Nomor 5043)

Undang-Undang Nomor 17 Tahun 2014 tentang MPR, DPR, DPD, dan DPRD. (Lembaran Negera Republik Indonesia Tahun 2014 Nomor 182, Tambahan Lembaran Negara Republik Indonesia Nomor 5568)

Putusan Mahkmah Konstitusi Republik Indonesia Nomor 36/PUU-XV/2017 Tentang Pengujian Undang-Undang No. 17 Tahun 2014 tentang MPR, DPR, DPD, dan DPRD terhadap UUD NRI 1945.

Putusan Mahkamah Konstitusi Republik Indonesia Nomor 40/PUU-XV/2017 Tentang Pengujian Undang-Undang No. 17 Tahun 2014 tentang MPR, DPR, DPD, dan DPRD terhadap UUD NRI 1945.

Rancangan Undang-Undang Tentang Komisi Pemberantasan Tindak Pidana Korupsi yang telah disetujui serta belum disahkan dan dibukukan ke lembaran negara. 
Peraturan Dewan Perwakilan Rakyat Republik Indonesia Nomor 1 Tahun 2014 Tentang Tata Tertib

\section{Konstitusi di berbagai Negara dan dokumen lainnya}

Constitution of The Republic of South Africa No. 108 of 1996. Avalaible at https://www.gov.za/sites/default/files/images/a108-96.pdf. Diakses pada tanggal 2 Oktober 2019.

Egypt's Constitution of 2014. Avalaible at https://www.constituteproject.org/ constitution/Egypt_2014.pdf. diakses pada tanggal 2 Oktober 2019.

Thailand's Constitution of 2014, constituteproject.org. Diakses pada tanggal 22 Februari 2018.

The 1987 Constitution of The Republic of The Philippines Vide, https://www. parliament.gov.za/what-parliament-does

United States of America's Constitution of 1789 with Amendments through 1992. Avalaible at https://www.constituteproject.org/constitution/United_States of_America_1992.pdf?lang=en. Diakses pada tanggal 2 Oktober 2019

Zimbabwe's Constitution of 2013. Avalaible at https://www.constituteproject.org/ constitution/Zimbabwe_2013.pdf. Diakses pada tanggal 2 Oktober 2019

\section{Website}

https://acch.kpk.go.id/id/statistik/tindak-pidana-korupsi/tpk-berdasarkan-profesijabatan.

https://www.parliament.gov.za/what-parliament-does

UNCAC Coalition, UNCAC Coalition Statement on threats to the independence of Indonesia's Corruption Eradication Commission KPK, 27.09.2019. https://uncaccoalition.org/wp-content/uploads/Indonesia-statement-onKPK-\%E2\%80\%93-27092019.pdf 